\title{
Folic Acid Conjugates for Nuclear Imaging of Folate Receptor-Positive Cancer
}

\author{
Cristina Müller ${ }^{1}$ and Roger Schibli ${ }^{1,2}$ \\ ${ }^{I}$ Center for Radiopharmaceutical Sciences ETH-PSI-USZ, Paul Scherrer Institute, Villigen-PSI, Switzerland; and ${ }^{2}$ Department of \\ Chemistry and Applied Biosciences, ETH Zurich, Zurich, Switzerland
}

The folate receptor (FR) is overexpressed on a variety of tumor types, whereas its distribution in normal tissues and organs is highly limited. Exploration of the utility of the FR revealed its promising potential for targeting with folate-based radiopharmaceuticals. Herein, we report the principle of the FR-targeting strategy and summarize the development of several folic acid radioconjugates useful for SPECT and PET of cancer diseases. The potential applicability of folate radiopharmaceuticals for FR-targeted radionuclide therapy is also discussed.

Key Words: folic acid; folate receptor; SPECT; PET; cancer J Nucl Med 2011; 52:1-4

DOI: 10.2967/jnumed.110.076018

Because the availability of efficient and reliable tools for noninvasive diagnosis of diseases is crucial for their management and, thus, for the improvement of a patient's quality of life, identification of targets that are specifically associated with diseased cells is of primary interest. In this respect, the folate receptor (FR) has been intensively studied over almost 2 decades because of its frequent overexpression in cancer cells and its ability to bind and internalize folic acid and conjugates thereof (1).

Folates and folic acid in its oxidized form are water-soluble vitamins of the B-complex group that are exogenously required for optimal health, growth, and development. Folate vitamins act as cofactors for enzymes that are involved in the biosynthesis of DNA and RNA, the amino acid metabolism and epigenetic processes. Thus, folates play a key role for cellular survival and proliferation, whereas impairment of the folate-dependent systems causes several pathophysiologic conditions. Because the hydrophilic nature of folates precludes passive diffusion through the plasma membrane, efficient transport mechanisms are necessary to allow cells the uptake of these essential nutrients. In normal cells, transport is accomplished primarily through the reduced folate carrier (2) and the proton-coupled folate transporter (3). The third uptake system is the high-affinity FR, a glycosyl phosphatidyl inositol-anchored glycoprotein $(38-45 \mathrm{kDa})$ that binds preferentially folic acid $\left(\mathrm{K}_{\mathrm{d}} \approx 10^{-9} \mathrm{M}\right)$ and 5-methyltetrahydrofolate and is internalized via endocytosis (4).

Received Jun. 23, 2010; revision accepted Sep. 8, 2010.

For correspondence or reprints contact: Cristina Müller, Center for Radiopharmaceutical Sciences ETH-PSI-USZ, Paul Scherrer Institute, CH5232 Villigen-PSI, Switzerland.

E-mail: cristina.mueller@psi.ch

COPYRIGHT (c) 2011 by the Society of Nuclear Medicine, Inc.
In healthy tissues, FR expression is restricted to the lungs, the kidneys, the placenta, and the choroid plexus, where it is confined to the apical surface of polarized epithelia (5). Importantly, the FR is often present in large numbers on epithelial cancers, including tumors of the ovary, cervix, endometrium, lung, kidney, breast, colon, and brain $(5,6)$. Investigations of a variety of FR-positive cancer types revealed that of all the types tested, those of ovarian origin displayed elevated FR levels most frequently (5). The FR is also expressed on hematopoietic malignancies of myeloid origin, including chronic and acute myelogenous leukemias (7). Other tumors, such as sarcomas, lymphomas, pancreatic and testicular cancer, and cancer of the bladder, prostate, and liver, do not commonly upregulate the FR (5).

\section{PRINCIPLE OF FR-TARGETED CANCER RADIOIMAGING}

The concept of the FR-targeting strategy makes use of the vitamin folic acid as a molecular Trojan horse for selective delivery of attached probes to FR-expressing cancer cells (Fig. 1). Compared with other targeting agents, such as monoclonal antibodies or peptides, folic acid offers several advantages. It is small (441 Da), stable over a broad range of temperatures and $\mathrm{pH}$ values, and thus amenable for site-specific chemical modification. It is inexpensive, nonimmunogenic, and binds to the FR with high affinity even after conjugation to a diagnostic or therapeutic cargo.

Because folic acid-targeted imaging agents can serve as noninvasive diagnostic tools to assess the location and severity of FRpositive cancer, a variety of folic acid-conjugated imaging agents have been developed and evaluated in vitro and in vivo. Folic acid conjugates of probes for optical imaging, MRI, and nuclear imaging by SPECT and PET are reported in the literature (Fig. 1) $(8,9)$. Because of the outstanding features of SPECT and PET (e.g., high sensitivity) the overall usage of nuclear medicine procedures is expanding rapidly. Thus, recently, folate-based SPECT and PET tracers have attracted the greatest interest.

\section{FOLIC ACID RADIOCONJUGATES}

\section{Radiofolates for SPECT and Potential Therapy}

One of the first designs of a folic acid radioconjugate for SPECT used deferoxamine for chelation of the $\gamma$-emitting radioisotope ${ }^{67} \mathrm{Ga}$ (10). Tumor targeting was successfully achieved with ${ }^{67} \mathrm{Ga}$-deferoxamine-folate in mice bearing FR-positive tumor xenografts $(\sim 8.5$ percentage injected dose per gram [\%ID/g], $4 \mathrm{~h}$ after injection). However, significant hepatobiliary excretion of the tracer led to unfavorable abdominal accumulation of radioactivity (11). With the aim of 


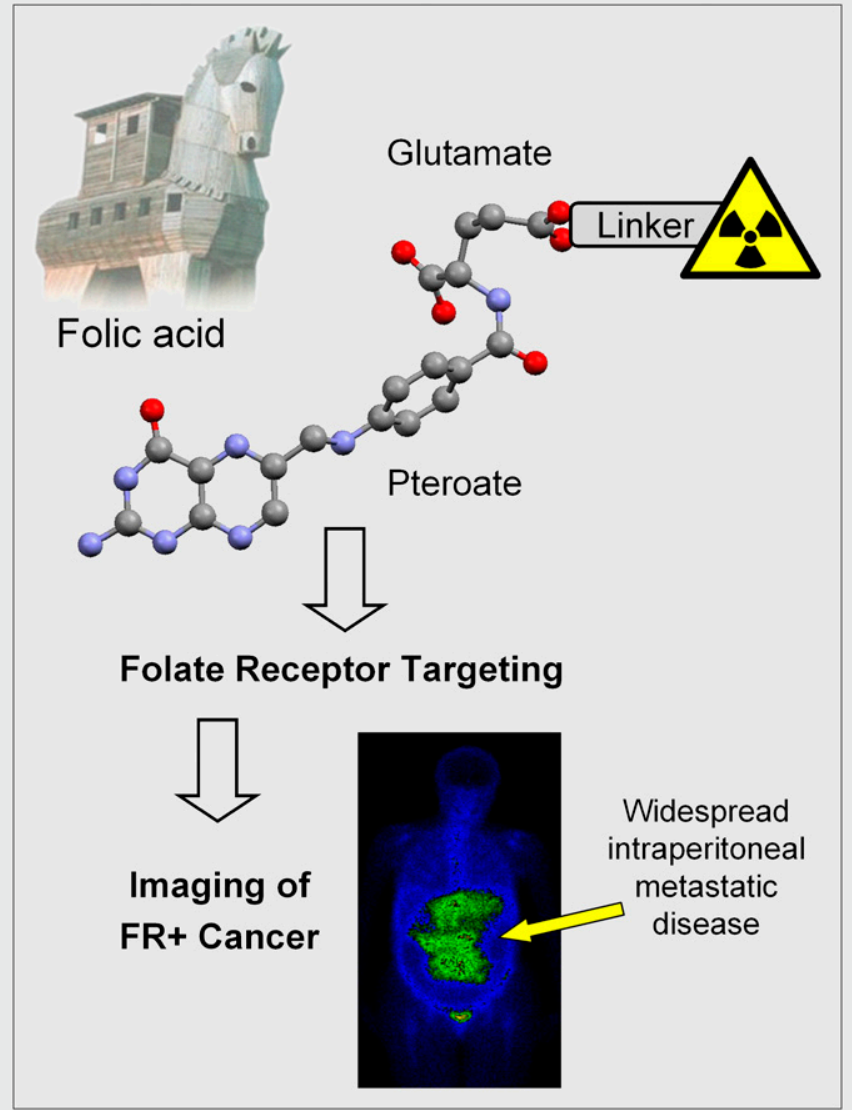

FIGURE 1. Principle of FR-targeted nuclear imaging: radioactive probe is linked to folic acid (pteroylglutamic acid) via glutamate moiety, whereas pteroate moiety is essential for FR binding on cancer cells. SPECT image of cancer patient injected with ${ }^{99 m T c-E C 20 ~(p a t i e n t ~}$ scan courtesy of Christopher P. Leamon, Endocyte Inc.).

designing a more hydrophilic tracer, a folic acid conjugate with a diethylenetriamine pentaacetate (DTPA) chelator has been developed for radiolabeling with the SPECT isotope ${ }^{111} \mathrm{In}$ ( $\gamma$-radiation: energy $[\mathrm{E}]=171 \mathrm{keV}, 245 \mathrm{keV}$, half-life $\left.\left[\mathrm{t}_{1 / 2}\right]=2.8 \mathrm{~d}\right) .{ }^{111}$ In-DTPA-folate was found to clear about $97 \%$ through the kidneys, with negligible uptake in the peritoneal cavity (12). On the basis of encouraging preclinical data, ${ }^{111}$ In-DTPA-folate was tested in clinical trials (13). The tracer was impressively shown to accumulate specifically in FR-positive malignancies of patients with ovarian and endometrial cancer, whereas radioactivity accumulation in normal tissues and organs was observed only in the kidneys and, in some patients, in the liver and spleen.

For SPECT purposes with folate-based nuclear imaging agents, ${ }^{99 \mathrm{~m}} \mathrm{Tc}$ has emerged as the preferred radionuclide because of its ideal physical decay properties ( $\gamma$-radiation: $\mathrm{E}=140 \mathrm{keV}, \mathrm{t}_{1 / 2}=6 \mathrm{~h}$ ), its low cost, and the development of a generator system that makes it readily available on-site in any hospital. Guo et al. reported the synthesis and evaluation of a hydrazinonicotinamide-folate conjugate (14). Hydrazinonicotinamide serves as a monodentate ligand for the octahedral technetium center, whereas the remaining 5 coordination sites about the ${ }^{99 \mathrm{~m}} \mathrm{Tc}-$ metal center are occupied by coligands such as tricine and trisodium triphenylphosphine trisulfonate. The preclinical evaluation of the $99 \mathrm{~m} \mathrm{Tc}$-hydrazinonicotinamide-folate was performed with C57BL/6 mice bearing subcutaneous 24JKFBP tumors (mouse sarcoma cells transfected with the human FR). The ${ }^{99 m} \mathrm{Tc}$-folate tracer displayed considerable and FR-specific tumor uptake $(\sim 17.8 \% \mathrm{ID} / \mathrm{g}, 4 \mathrm{~h}$ after injection), which declined to background levels if the mice received a coinjection of excess folic acid. Probably the most promising ${ }^{99 \mathrm{~m}} \mathrm{Tc}$-folate candidate is ${ }^{99 \mathrm{~m}} \mathrm{Tc}-\mathrm{EC} 20$, wherein ${ }^{99 \mathrm{~m}} \mathrm{Tc}(\mathrm{V})$ is complexed by a short folatelinked peptide (Cys-Asp-Dap-D-Glu-Pte) (Fig. 2) (15). The in vivo experiments of ${ }^{99 \mathrm{~m}} \mathrm{Tc}-\mathrm{EC} 20$ were performed on a BALB/c mouse model with syngeneic FR-positive M109 tumors. On the basis of excellent preclinical data that showed a high tumor uptake $(\sim 17.7$ $\% \mathrm{ID} / \mathrm{g}, 4 \mathrm{~h}$ after injection) and elimination primarily via the kidneys, ${ }^{99 \mathrm{~m}}$ Tc-EC20 was introduced into the clinic, where it has been used to image several hundred patients to date. In one clinical trial, imaging with ${ }^{99 \mathrm{~m}} \mathrm{Tc}-\mathrm{EC} 20$ was performed on 155 patients with a variety of solid tumors (16). The results demonstrated that $68 \%$ of the patients showed uptake of ${ }^{99 \mathrm{~m}} \mathrm{Tc}-\mathrm{EC} 20$ in their tumors. Accumulation of ${ }^{99 \mathrm{~m}} \mathrm{Tc}-\mathrm{EC} 20$ was also noted in the kidneys and bladder of almost all patients, consistent with the expression of FRs on the proximal tubules of the kidney and the urinary excretion of the tracer. Mild to marked uptake of radioactivity in the liver was blockable by inhibitors of organic anion transport, suggesting mechanisms other than FR binding (16). The authors concluded that ${ }^{99 \mathrm{~m}} \mathrm{Tc}-\mathrm{EC} 20$ imaging is a safe, noninvasive procedure that may identify FRs in recurrent or metastatic diseases without the need for biopsy to identify patients who may benefit from treatment with FR-targeted therapy.

A completely different strategy was approached while developing organometallic ${ }^{99 \mathrm{~m}} \mathrm{Tc}$-folates (17). The water- and air-stable organometallic tricarbonyl complex $\left[{ }^{99 \mathrm{~m}} \mathrm{Tc}\left(\mathrm{H}_{2} \mathrm{O}\right)_{3}(\mathrm{CO})_{3}\right]^{+}$was previously proved to be a versatile reagent for labeling a variety of bioconjugates with ${ }^{99 \mathrm{~m}} \mathrm{Tc}$. Importantly, this strategy potentially allows the synthesis of isostructural compounds for diagnosis and therapy while using the "matched" pair ${ }^{99 m} \mathrm{Tc} /{ }^{188} \operatorname{Re}\left({ }^{188} \mathrm{Re}: \beta^{-}\right.$-decay, average $\mathrm{E}\left[\mathrm{E}_{\mathrm{av}}\right]=$ $763 \mathrm{keV}, \gamma$-radiation, $\mathrm{E}=155 \mathrm{keV}, \mathrm{t}_{1 / 2}=17 \mathrm{~h}$ ) (18). A series of organometallic ${ }^{99 \mathrm{~m}} \mathrm{Tc}$-folate derivatives has been developed and evaluated. In vivo, these tracers exhibited specific uptake in FR-positive tumors $(\sim 2-4 \% \mathrm{ID} / \mathrm{g}, 4 \mathrm{~h}$ after injection) and kidneys. Undesirably, ${ }^{99} \mathrm{~m} \mathrm{Tc}(\mathrm{CO})_{3}$-radiofolates accumulated to a significant extent in the intestinal tract as a consequence of the hydrophobic character of the tricarbonyl-moiety. The most promising organometallic folate tracer, ${ }^{99 \mathrm{~m}} \mathrm{Tc}(\mathrm{CO})_{3}$-histidine-folate (Fig. 2), was used for preclinical imaging studies of tumor-bearing mice with a small-animal multipinhole SPECT/CT scanner (19). This study allowed precise determination of radioactivity uptake and distribution in FR-expressing tissues and organs such as KB tumor xenografts, kidneys, salivary glands, and the choroid plexus in the brain.

More recently, a folate conjugate with a DOTA chelator has been synthesized while using a "Click"-chemistry approach (Fig. 2) (20). This radioconjugate was successfully radiolabeled with ${ }^{111} \mathrm{In}$ for SPECT and with ${ }^{177} \mathrm{Lu}\left({ }^{177} \mathrm{Lu}: \beta^{-}\right.$-decay, $E_{\mathrm{av}}=134 \mathrm{keV}$, $\gamma$-radiation, $\mathrm{E}=113 \mathrm{keV}, 208 \mathrm{keV}, \mathrm{t}_{1 / 2}=6.7 \mathrm{~d}$ ) for potential therapeutic application. In preclinical studies with tumor-bearing mice, the new folate radiotracer displayed an excellent overall tissue distribution with specific accumulation in FR-positive KB tumor xenografts $\left({ }^{111} \mathrm{In}, \sim 5.8 \% \mathrm{ID} / \mathrm{g}\right.$, and ${ }^{177} \mathrm{Lu}, 7.5 \% \mathrm{ID} / \mathrm{g}, 4 \mathrm{~h}$ after injection) but with minimal radioactivity retention in nontargeted organs and tissues (21). Significant uptake was, however, observed in the kidneys, resulting in the same low tumor-to-kidney ratios $(<0.15)$ that were observed with previously evaluated radiofolates.

\section{Radiofolates for PET}

The development of a folate-based PET agent is an attractive concept because PET would be the most accurate method for noninvasive 


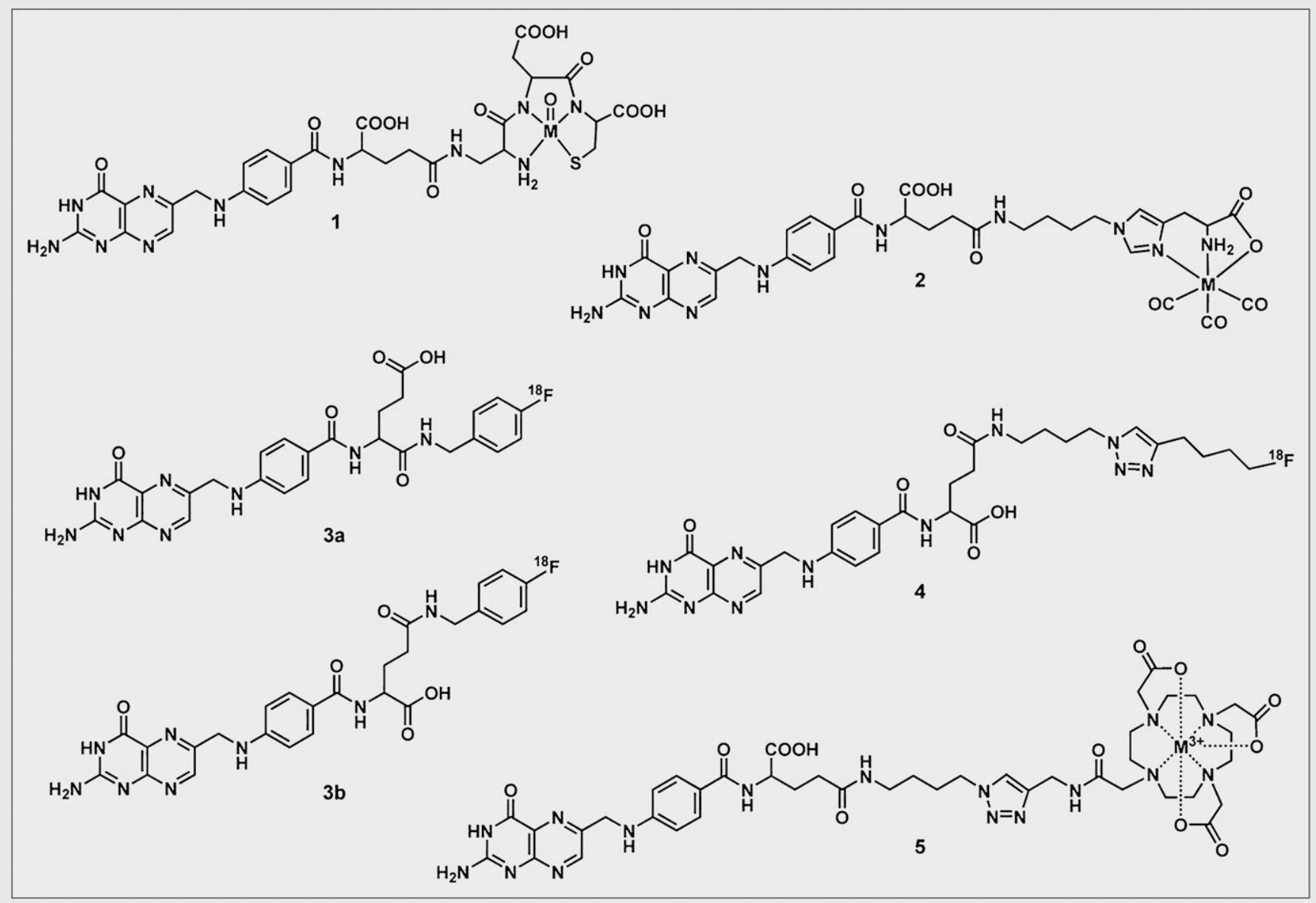

FIGURE 2. Chemical structures of folic acid radioconjugates: ${ }^{99 m T c-E C 20 ~(M ~=~}{ }^{99 m T c) ~(1), ~}{ }^{99 m T c}(\mathrm{CO}){ }_{3}$-histidine-folate (M = $\left.99 \mathrm{mTc}\right)(2)$, ${ }^{18} \mathrm{~F}-$ fluorobenzylamine- $\alpha$-folate (3a), ${ }^{18} \mathrm{~F}$-fluorobenzylamine- $\gamma$-folate $(3 \mathrm{~b}),{ }^{18} \mathrm{~F}$-Click-folate (4), and DOTA-Click-folate $\left(\mathrm{M}={ }^{111} \mathrm{In}\right.$, $\left.{ }^{177} \mathrm{Lu}\right)(5)$.

diagnosis of cancer, particularly of small metastases. Mathias et al. reported the radiosynthesis of the first PET folate tracers, ${ }^{66} \mathrm{Ga}$ - and ${ }^{68} \mathrm{Ga}$-deferoxamine-folate $(22) .{ }^{68} \mathrm{Ga}$ is a generator isotope with a short half-life $\left(89 \% \beta^{+}\right.$-decay, $\left.\mathrm{E}_{\mathrm{av}}=830 \mathrm{keV}, \mathrm{t}_{1 / 2}=68 \mathrm{~min}\right)$, whereas ${ }^{66} \mathrm{Ga}$ has a relatively long half-life but an unfavorably high positron energy $\left(56 \% \beta^{+}\right.$-decay, $\left.E_{a v}=1,740 \mathrm{keV}, \mathrm{t}_{1 / 2}=9.5 \mathrm{~h}\right)$. In this study, FR-positive tumors and kidneys were clearly visualized on small-animal PET images of a KB tumor-bearing mouse $25 \mathrm{~h}$ after injection of ${ }^{66} \mathrm{Ga}$-deferoxamine-folate. However, the same drawback of a high intestinal accumulation of radioactivity that was reported for ${ }^{67} \mathrm{Ga}$-deferoxamine-folate also hampered a further development of these PET folates.

The design of a ${ }^{18} \mathrm{~F}$-radiolabeled folate tracer is a promising approach because, compared with other radionuclides, ${ }^{18} \mathrm{~F}(97 \%$ $\beta^{+}$-decay, $\mathrm{E}_{\mathrm{av}}=250 \mathrm{keV}, \mathrm{t}_{1 / 2}=110 \mathrm{~min}$ ) displays excellent decay characteristics for PET. The first ${ }^{18} \mathrm{~F}$-folate tracer reported in the literature was a folic acid conjugate with 4-fluorbenzylamine as a prosthetic group, referred to as ${ }^{18} \mathrm{~F}$-fluorobenzylamine-folate (Fig. 2) (23). ${ }^{18} \mathrm{~F}$-fluorobenzylamine was coupled with ester-activated folic acid to obtain $\gamma$ - and $\alpha-{ }^{18} \mathrm{~F}$-fluorobenzylamine-folate isomers in a ratio of $4: 1$. The last reaction step yielded $15 \%-44 \%{ }^{18} \mathrm{~F}-$ fluorobenzylamine-folate tracer after purification via highperformance liquid chromatography. PET studies performed with ${ }^{18} \mathrm{~F}$-fluorobenzylamine-folate in tumor-bearing mice were successful in visualizing $\mathrm{KB}$ tumor xenografts $(\sim 6.5 \% \mathrm{ID} / \mathrm{g}, 2 \mathrm{~h}$ after injection). Beside uptake in FR-expressing kidneys, massive radioactivity uptake was observed in the gallbladder $(>250 \% \mathrm{ID} / \mathrm{g}, 2 \mathrm{~h}$ after injection) and the intestinal tract. To address the drawback of a low radiochemical yield experienced with ${ }^{18} \mathrm{~F}$-fluorobenzylaminefolate, a more versatile radiosynthetic strategy was approached that used a Click-chemistry reaction (24). The folate precursor, folic acid- $\gamma$-(4-azido)-butylamide, was prepared according to a previously described method (25). The radiosynthesis of the ${ }^{18} \mathrm{~F}$ Click-folate (Fig. 2) comprised 2 main reaction steps. First, the prosthetic group, $6-{ }^{18} \mathrm{~F}$-fluoro-1-hexyne, was produced from the corresponding $p$-tosylate precursor with an excellent radiochemical yield $(70 \%-85 \%)$ and purity $(>95 \%)$. The second reaction step comprised the 1,4-triazole formation by $\mathrm{Cu}(\mathrm{I})$-catalyzed cycloaddition of the ${ }^{6-18} \mathrm{~F}$-fluoro-1-hexyne and folic acid $\gamma$-(4-azido)-butylamide. This Click reaction succeeded without the need for protection groups and directly provided the final ${ }^{18} \mathrm{~F}$-Click-folate (20). In vivo studies performed with $\mathrm{KB}$ tumor-bearing mice revealed a relatively high and FR-specific tumor uptake $(\sim 3 \% \mathrm{ID} / \mathrm{g}, 45 \mathrm{~min}$ after injection) and a reasonable tumor-to-kidney ratio. However, the strongly lipophilic character of the ${ }^{18} \mathrm{~F}$-Click-folate resulted again in high accumulation of radioactivity in the bile $(>600 \% \mathrm{ID} / \mathrm{g}, 45 \mathrm{~min}$ after injection) and in the intestinal tract. Because both of these ${ }^{18} \mathrm{~F}$-PET tracers provided suboptimal results, further investment in the design of ${ }^{18} \mathrm{~F}$-PET folates will be necessary for optimization of both the radiosynthesis and the in vivo properties of the tracer. 


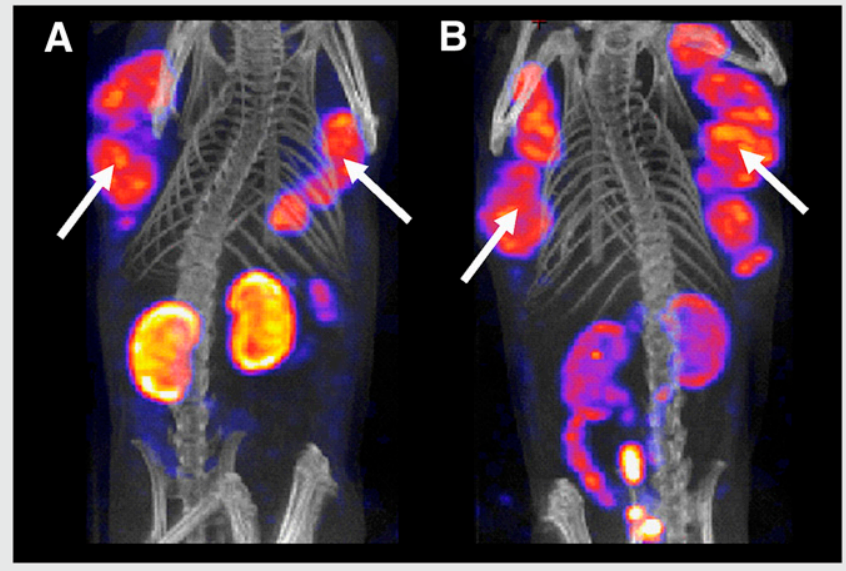

FIGURE 3. SPECT/CT images of female mice bearing human ovarian IGROV-1 tumor xenografts (arrows), $4 \mathrm{~h}$ after injection of ${ }^{111}$ In-DTPA-folate alone (A) and in combination with predosed pemetrexed (B) (28).

\section{PERSPECTIVE}

A critical aspect of the FR-targeting strategy is the physiologic expression of FRs in the kidneys. Reabsorption of folates from primary urine via FRs is a physiologic process that prevents constant loss of these important vitamins (26). Not surprisingly, small-molecular-weight folic acid radioconjugates undergo the same fate, which results in a significant renal uptake of radioactivity. Thus, folate-based radionuclide therapy with particle-emitting isotopes has not been envisaged so far because low tumor-to-kidney ratios $(<0.15)$ of radiofolates would present a high risk for damage to the kidneys.

Recent data suggest, however, that predosing with the antifolate pemetrexed significantly reduces kidney uptake of radiofolates while retaining the desired radiotracer accumulation in the tumor (Fig. 3) $(21,27,28)$. The exact underlying mechanism of this observation is not yet completely understood. However, the accessibility of reasonable tumor-to-kidney ratios allows a therapeutic application of radiofolates to be taken into consideration now. But the use of pemetrexed-a chemotherapeutic agent with potential side effects-only for the sake of kidney protection could be problematic. On the other hand, a potential synergistic anticancer effect of therapeutic radiofolates and pemetrexed would be a strong argument to justify the use of this combination for tumor treatment.

\section{CONCLUSION}

Using folic acid radioconjugates for SPECT and PET of cancer has proven to be a versatile strategy in preclinical and clinical studies. Although the SPECT tracer ${ }^{99 m}$ Tc-EC20 is currently used in the clinic, a suitable PET folate tracer is still lacking. The question of whether FR-targeted radionuclide therapy will be used in the future depends on an appropriate folate tracer design and on combination with substances that potentiate the therapeutic antitumor effect or protect individuals from the risk of nephropathy.

\section{REFERENCES}

1. Low PS, Henne WA, Doorneweerd DD. Discovery and development of folicacid-based receptor targeting for imaging and therapy of cancer and inflammatory diseases. Acc Chem Res. 2008;41:120-129.
2. Sirotnak FM, Tolner B. Carrier-mediated membrane transport of folates in mammalian cells. Аnпu Rev Nutr. 1999;19:91-122.

3. Qiu A, Jansen M, Sakaris A, et al. Identification of an intestinal folate transporter and the molecular basis for hereditary folate malabsorption. Cell. 2006;127:917-928.

4. Antony AC. Folate receptors. Annu Rev Nutr. 1996;16:501-521.

5. Parker N, Turk MJ, Westrick E, Lewis JD, Low PS, Leamon CP. Folate receptor expression in carcinomas and normal tissues determined by a quantitative radioligand binding assay. Anal Biochem. 2005;338:284-293.

6. Garin-Chesa P, Campbell I, Saigo PE, Lewis JL, Old LJ, Rettig WJ. Trophoblast and ovarian cancer antigen LK26: sensitivity and specificity in immunopathology and molecular identification as a folate-binding protein. Am J Pathol. 1993; 142:557-567.

7. Shen F, Ross JF, Wang X, Ratnam M. Identification of a novel folate receptor, a truncated receptor, and receptor type $\beta$ in hematopoietic cells: cDNA cloning, expression, immunoreactivity, and tissue specificity. Biochemistry. 1994;33: 1209-1215.

8. Ke CY, Mathias CJ, Green MA. Folate-receptor-targeted radionuclide imaging agents. Adv Drug Deliv Rev. 2004;56:1143-1160.

9. Sega EI, Low PS. Tumor detection using folate receptor-targeted imaging agents. Cancer Metastasis Rev. 2008;27:655-664.

10. Wang S, Lee RJ, Mathias CJ, Green MA, Low PS. Synthesis, purification, and tumor cell uptake of ${ }^{67} \mathrm{Ga}$-deferoxamine-folate, a potential radiopharmaceutical for tumor imaging. Bioconjug Chem. 1996;7:56-62.

11. Mathias CJ, Wang S, Low PS, Waters DJ, Green MA. Receptor-mediated targeting of ${ }^{67} \mathrm{Ga}$-deferoxamine-folate to folate-receptor-positive human $\mathrm{KB}$ tumor xenografts. Nucl Med Biol. 1999;26:23-25.

12. Mathias CJ, Wang S, Waters DJ, Turek JJ, Low PS, Green MA. Indium-111DTPA-folate as a potential folate-receptor-targeted radiopharmaceutical. J Nucl Med. 1998;39:1579-1585.

13. Siegel BA, Dehdashti F, Mutch DG, et al. Evaluation of ${ }^{111}$ In-DTPA-folate as a receptor-targeted diagnostic agent for ovarian cancer: initial clinical results. J Nucl Med. 2003;44:700-707.

14. Guo W, Hinkle GH, Lee RJ. ${ }^{99 \mathrm{~m}}$ Tc-HYNIC-folate: a novel receptor-based targeted radiopharmaceutical for tumor imaging. J Nucl Med. 1999;40:1563-1569.

15. Leamon CP, Parker MA, Vlahov IR, et al. Synthesis and biological evaluation of EC20: a new folate-derived, ${ }^{99 \mathrm{~m} T c-b a s e d ~ r a d i o p h a r m a c e u t i c a l . ~ B i o c o n j u g ~ C h e m . ~}$ 2002;13:1200-1210.

16. Fisher RE, Siegel BA, Edell SL, et al. Exploratory study of ${ }^{99 \mathrm{~m}} \mathrm{Tc}-\mathrm{EC} 20$ imaging for identifying patients with folate receptor-positive solid tumors. $J$ Nucl Med. 2008;49:899-906

17. Müller C, Schubiger PA, Schibli R. Synthesis and in vitro/in vivo evaluation of

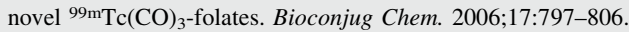

18. Alberto R, Schibli R, Waibel R, Abram U, Schubiger AP. Basic aqueous chemistry of $\left[\mathrm{M}\left(\mathrm{OH}_{2}\right)_{3}(\mathrm{CO})_{3}\right]^{+}(\mathrm{M}=\mathrm{Re}, \mathrm{Tc})$ directed towards radiopharmaceutical application. Coord Chem Rev. 1999;192:901-919.

19. Müller C, Forrer F, Schibli R, Krenning EP, de Jong M. SPECT study of folate receptor-positive malignant and normal tissues in mice using a novel ${ }^{99 \mathrm{~m}} \mathrm{Tc}$ radiofolate. J Nucl Med. 2008;49:310-317.

20. Mindt TL, Müller C, Stuker F, et al. A "click chemistry" approach to the efficient synthesis of multiple imaging probes derived from a single precursor. Bioconjug Chem. 2009;20:1940-1949.

21. Müller C, Mindt TL, de Jong M, Schibli R. Evaluation of a novel radiofolate in tumour-bearing mice: promising prospects for folate-based radionuclide therapy. Eur J Nucl Med Mol Imaging. 2009;36:938-946.

22. Mathias CJ, Lewis MR, Reichert DE, et al. Preparation of ${ }^{66} \mathrm{Ga}$ - and ${ }^{68} \mathrm{Ga}-$ labeled $\mathrm{Ga}(\mathrm{III})$-deferoxamine-folate as potential folate-receptor-targeted PET radiopharmaceuticals. Nucl Med Biol. 2003;30:725-731.

23. Bettio A, Honer M, Müller C, et al. Synthesis and preclinical evaluation of a folic acid derivative labeled with ${ }^{18} \mathrm{~F}$ for PET imaging of folate receptor-positive tumors. J Nucl Med. 2006;47:1153-1160.

24. Ross TL, Honer M, Lam PYH, et al. Fluorine-18 click radiosynthesis and preclinical evaluation of a new ${ }^{18} \mathrm{~F}$-labeled folic acid derivative. Bioconjug Chem. 2008;19:2462-2470.

25. Mindt TL, Müller C, Melis M, de Jong M, Schibli R. "Click-to-chelate": in vitro and in vivo comparison of a ${ }^{99 \mathrm{~m}} \mathrm{Tc}(\mathrm{CO})_{3}$-labeled $\mathrm{N}(\mathrm{tau})$-histidine folate derivative with its isostructural, clicked 1,2,3-triazole analogue. Bioconjug Chem. 2008;19:1689-1695.

26. Birn H, Spiegelstein O, Christensen EI, Finnell RH. Renal tubular reabsorption of folate mediated by folate binding protein 1. J Am Soc Nephrol. 2005;16:608-615.

27. Müller C, Brühlmeier M, Schubiger AP, Schibli R. Effects of antifolate drugs on the cellular uptake of radiofolates in vitro and in vivo. J Nucl Med. 2006;47:2057-2064.

28. Müller C, Schibli R, Krenning EP, de Jong M. Pemetrexed improves tumor selectivity of ${ }^{111}$ In-DTPA-folate in mice with folate receptor-positive ovarian cancer. J Nucl Med. 2008;49:623-629. 